\title{
PMO Managers' Self-Determined Participation in a Purposeful Virtual Community-of-Practice
}

\author{
By: \\ Liz Lee-Kelley* \\ Cranfield University, Cranfield, MK43 0AL, UK \\ Email: liz.lee-kelley@cranfield.ac.uk \\ $\&$ \\ Neil Turner \\ Cranfield University, Cranfield, MK43 0AL, UK \\ Email: neil.turner@cranfield.ac.uk
}

* Corresponding author 


\title{
PMO Managers' Self-Determined Participation in a Purposeful Virtual Community-Of-Practice
}

\begin{abstract}
Communities-of-practice (CoPs) have received significant attention within a variety of literatures but we remain largely ignorant of the potential of purposefully-created CoPs for professionals in global organisations. In this context, the challenge is likely to be convincing 'masters' (Wenger, 1998) on the merits of joining the conversation on practice at a distance, thus making the willingness for exchange a key to the quality and longevity of the community. We posed the question "Why would busy, dispersed, knowledgeable project professionals want to join and participate in a deliberately-organised CoP?" Our 2-year collaborative action research design allowed us to observe the CoP and its membership at close range. We conclude that autonomy, competence and belonging underscore participation, co-production and diffusion of innovative problem-solving and practice beyond the CoP to local personal networks. The study will inform organisations contemplating similar interventions and we hope that it will provide the basis and impetus for further investigation and theory building by colleagues from the research community.
\end{abstract}

Key words: communities-of-practice, knowledge-sharing, PMO, action research, motivation. 


\section{Introduction}

Organisational theorists such as Galbraith (1994) and Weick and Roberts (1994) had long foreseen peer group connection as a critical challenge in knowledge-intensive organisations (KIOs). The lament, 'If only HP knew what HP knows' by a former CEO (Brown and Duguid, 2002, p429) reflects early claims that knowledge is a key source of competitive advantage (Grant, 1996). This is reflected in the large body of research that has been undertaken regarding knowledge in the context of projects (e.g. Ahern et al., 2014; Bosch-Sijtsema.and Henriksson, 2014; Holzmann, 2013; Pemsel and Müller, 2012; Pemsel et al., 2014; Reich, Gemino,and Sauer, 2012; Turner et al., 2014), with the recognition that learning is both valuable and difficult in this environment.

In this paper we bring together two themes within the literature. First, an important line of inquiry around knowledge production and flow throughout the organisation is the notion of communities-ofpractice (CoPs). Second, the role of the Project Management Office (PMO) has also been investigated in terms of its benefits as a repository of knowledge and also in promoting knowledge-sharing within the organisation. However, the role of community-based learning incorporating the PMO is lacking. We chronicle an intervention with a major IT-services organisation to set up a virtual $\mathrm{CoP}$ for the purpose of sharing effective practices across dispersed and unconnected groups and individuals and investigate the motivations of those involved.

The paper is structured as follows. Initially we identify the literature that is the basis for our research and explain the relevance of self-determination theory for the project. We then introduce the case organisation and provide a working definition of the case CoP before detailing our collaborative action research design. As the sponsoring organisation did not specify outcome or performance metrics in advance of the intervention, we demonstrate observable aspects of community formation and participation (i.e. membership, attendance and outputs from joint activities). We discuss the findings and their implications for practice and theory. The paper concludes with a call for further research in what is as yet, a little understood but important aspect of organisational communities-ofpractice. 


\section{Literature}

There is a significant body of literature investigating the role of learning in projects which indicates the benefits that can be obtained (Carrillo, Ruikar and Fuller, 2013; Eriksson, 2013; Sense, 2011; Fernandes, Ward and Araújo, 2015). This incorporates learning in projects and programmes (Arthur, DeFillippi and Jones, 2001; Ayas and Zeniuk, 2001; Brady and Davies, 2004; Davies and Brady, 2000; Duffield and Whitty, 2016; Dutton, Turner and Lee-Kelley, 2014; Keegan and Turner, 2001; Scarbrough et al., 2004; Swan, Scarbrough and Newell, 2010), knowledge transfer and integration (Cacciatori, Tamoschus and Grabher, 2012; Enberg, Lindkvist and Tell, 2006), and an 'exploratory', problem-solving, approach (Geraldi, Kutsch and Turner, 2011; Klein and Meckling, 1958; Lenfle, 2008, 2014; Lenfle and Loch, 2010). Although learning lessons from projects is a laudable goal, this is very difficult for organisations to achieve in practice (Williams, 2008).

In line with this is the role of PMOs as repositories of learning and as vehicles enabling knowledge transfer (Artto et al., 2011; Dutton et al., 2014; Julian, 2008; Liu and Yetton, 2007; Pemsel and Wiewiora, 2013; Unger, Gemünden and Aubry, 2012). The wide variation of PMO sizes, functions and activities precludes 'one-size-fits-all' recommendations, but these organisational arrangements do appear to be valuable in catalysing and improving learning. Capturing and disseminating knowledge from a variety of distributed PMOs does not appear to have been well studied, though.

An alternative perspective is to take a more 'social' view of the phenomenon of learning. Lave and Wenger (1991) first developed the CoP concept to represent a situated activity system where more experienced members can impart their knowledge to less experienced colleagues. This was later refined by Wenger (1998) as the continuing interaction by a group of people with common concerns and problems or a passion for a subject, or who are looking for practice improvement. Wenger (1998) explains that there are two components of participation: the physical act of taking action and the 'monuments', instruments and points of focus around which people can connect and establish a 
shared identity. The underlying assumption remains: extended participation promotes rich exchange and identity formation, leading ultimately to a cohesive community capable of innovative solutions (Brown and Duguid, 1991, 1998; Gherardi and Nicolini, 2000; Liedtka, 1999; Tagliaventi and Mattarelli, 2006). Hence, social interaction rather than pure managerial 'process' (Bartsch, Ebers and Maurer, 2013; Di Vincenzo and Mascia, 2012; Han and Horav, 2013; Lee, Park and Lee, 2015) is central to the effectiveness of the community. To the above we would add that Wenger's (1998) subsequent refinement suggesting mutual sharing rather than a directional flow of knowledge has significance for knowledge-based project organisations and the willingness to connect is key to the longevity of any community.

Definitional differences have surfaced as business models become more transient and remote (Lindkvist, 2005; Murillo, 2011), prompting some to insist that the CoP concept is still largely normative and under-operationalised (e,g, Koliba and Gajda, 2009; Roberts, 2006). Others are concerned that its evolution into an all-encompassing construct is at the expense of other group-level constructs (e.g. Amin and Roberts, 2008; Lindkvist, 2005). Arguably, the resultant proliferation of labels can create further confusion, diverting researchers from finding out what a community is to worrying about what it should be (Bell and Newby, 1974). Examples include: communities of knowing (Boland and Tenkasi, 1995); community of practitioners (Gherardi, 2006); communities of interest (Fischer, 2001); collectivities of practice (Lindkvist, 2005); epistemic communities (Gittelman, 2007); collaborative networks (Ahuja, 2000); networks of practice (Brown and Duguid, 2001; Van de Ven, 2005) and constellations of interconnected practices (Gherardi and Nicolini, 2002). Each claims to describe a specific set of social practices or level of relationships within an organisation or society but their boundaries are not always definitive. Certainly Lindkvist (2005) is of the opinion that the term constellation displays too many CoP-like characteristics to be useful as an independent analytical category.

Distinguishing between 'old' and 'new' practices, we compared and contrasted Wenger and Snyder's (2000) community characteristics of high trust, strong shared cognitions and mutual commitment with 
Lindkvist's (2005) alternative notion of collectivities characterised by strong goal and task orientations, transient relationships and transactive socialisation. Distilling their different properties, we surmised that learning in more traditional self-generated communities is unintentional, paradigmatic and contextualised through extended situated practice whereas learning in the modern distributed collectivities is goal-oriented, solutions-focused and individualised. We also drew upon the concept of disciplinary networks of practice (Brown and Duguid, 2001) where, as with the Project Management Office employees in this study (discussed shortly), individuals by virtue of their practice will have access to other practitioners through their professional associations. We believed the different epistemological maxims could be used to elaborate motivation for knowledge transference in the case organisation.

Working on the notion that management has a responsibility to harness fragmented practices across the organisation for increased competitiveness (Argote and Ingram, 2000; Brown and Duguid, 2001; Wenger and Snyder, 2000) many companies have assimilated existing informal communities into their formal structures (see McDermott and Archibald, 2010). Others have intentionally initiated organisational CoPs (Meeuwesen and Berends, 2007; Swan, Scarborough and Robertson, 2002). Yet, importantly, Roberts (2006) appears unconvinced that management can engineer a CoP successfully. The need to balance control and autonomy is an unresolved management dilemma especially in dispersed networks (Agterberg, van den Hooff, Huysmann and Soekijad, 2009). Meanwhile, as more powerful technology arrives, a new generation of web-based communities has emerged moving away from the concept of situated to trans-situated computer-mediated learning (Vaast and Walsham, 2009). Examples from the field include Java Inc's (Songini, 2003) sponsorship of a number of global virtual communities to encourage developers to trade notes and share codes, and Caterpillar Inc's (Powers, 2004) web-based system of 3000 tightly focused CoPs across its construction and mining business divisions. These developments require the continuing reconceptualisation of the CoP notion and close examination of their effectiveness. 
Although there is general agreement on the beneficial potential of both spontaneous and purposeful CoPs, Polanyi's (1957) thesis that much of our knowledge and understanding is tacit and embedded in a specific context led us to note that the literature is particularly sparse on organisationally instigated CoPs for dispersed, knowledgeable individuals in support functions. Prior research has long reported knowledge 'stickiness' tendencies and resistance against managed knowledge flows in organisations (Sulanski, 1996; Von Hippel, 1994, 1999). We posit that in this context the challenge for management is not about getting experienced individuals to learn to become more competent members but about convincing 'masters' (Wenger, 1998) on the merits of joining the conversation on practice at a distance. This is central to being able to set up a CoP. Our quest, therefore, was to uncover the reasons and outcomes of sharing by these people. We ask, "Why would busy, dispersed, project support professionals want to join and participate in a deliberately-organised CoP?"

A review of the motivation literature suggests the answer is not straightforward. A number of recent studies on knowledge sharing in virtual communities (e.g. Chiu, Hsu and Wang, 2006; Cho, Chen and Chung, 2010; He and Wei, 2009) seek to provide insight on the influence of level or type of motivation on the propensity for exchange. Research in information sharing and group decisions report mixed and often, juxtaposed competitive and cooperative motives (e.g. Brodbeck, Kerschreiter, Mojzisch and Schulz-Hardt, 2007; De Dreu, Nijstad and van Knippenber, 2008; Wittenbaum, Hollingshead and Botero, 2004), often having to rely on extrinsic incentives (Kalman, Monge, Fulk and Heino, 2002). Other authors such as Agterberg et al. (2010), Thompson (2005) and Quigley, Tesluk, Locke and Bartol (2007) are interested in creating the necessary epistemic conditions and manipulating environmental factors (e.g. community structure, content, ways of connections) to encourage sharing. Indeed, Gilson et al. (2015) identify that although there has been a wealth of research, there is still much we do not know about virtual groups.

We view the current additive and externally regulated focus of conventional motivation models as tending to provide insight on the 'what' (the total level or kinds of motivation) and 'how' (the mechanisms to regulate behaviour) of sharing rather than understanding 'why' people are really 
motivated. In order to investigate this further, we drew upon self-determination theory (SDT) (Deci and Ryan, 1985; Deci, Koestner and Ryan, 1999; Gagné, 2009; Gagné and Deci, 2005; Ryan and Deci, 2000). This is a well-validated, multi-dimensional theory originating from psychological needs research and has been used in a broad range of applied domains such as education, health, sport management, marketing and consumer research. Two component sub-theories: cognitive evaluation theory (CET) and Organismic Integration Theory (OIT) underpin SDT's primary needs thesis of autonomy, competence and sense of belonging (Bandura, 1982, 1997; Baumeister and Leary, 1995; Deci and Ryan, 1985; Vallerand, 1995). Additionally, SDT uses two key terms: controlled and autonomous motivation (see also Ajzen, 1991; Ajzen and Fishbein, 1980). While acknowledging conventional wisdom that intrinsic and extrinsic regulation underscore individual motivation, in SDT's terms, controlled motivation aims to encourage desired behaviours through a variety of extrinsic reward-punishment mechanisms such as public or peer recognition and staff performance evaluation schemes. External regulators affect perceptions of personal autonomy, and this may account for reports of resistance to organised knowledge flows. Deadlines, directives, and competitive pressure are also experienced as behaviour-controlling mechanisms. If used excessively or negatively these extrinsic levers can prompt a change in the perceived locus of causality (deCharms, 1968) undermining a person's intrinsic interest in the task and feelings of competence. Autonomous motivation, on the other hand, assumes people are able to choose activities that are intrinsically meaningful or interesting to them. Gagné and Deci (2005) based their model of knowledge sharing motivation on SDT to explain variance in sharing behaviour, arguing that competence and choice ability are not only intrinsic regulators, they are considered the most autonomous form of motivation. Another study by Poortvliet et al. (2007) supports Gagné and Deci’s (2005) unease that controlled motivation will lead to positive outcomes especially when people sense that their actions and behaviours are being manipulated by the establishment. SDT's autonomy, competence and sense of belonging can unlock the mystery behind the seeking and sharing behaviours of already experienced and knowledgeable workers in large and global organisations. 
Our project was to understand the self-determined nature of CoP participation by busy, distributed, project professionals. It was a component of a larger 5-year programme of research with Hewlett Packard Enterprise Services (HPES). The 2-year collaborative research design allowed us to observe the deliberate $\mathrm{CoP}$ at close range. We believe our observations of different contexts, client-oriented task objectives and personal need drivers extend our understanding of modern CoP participation.

In line with our definitions discussion above and given that the mandate by HPES was to develop a professional PMO community guided by 'specific goals, explicit accountability and clear executive oversight' (McDermott and Archibald 2010:84) we define the purposeful virtual CoP as 'a community designed and implemented as an organisational intervention, utilising multiple synchronous and asynchronous electronic platforms to enable local, project and organisational peer-to-peer engagement and mutual learning'. This definition shares the assumption that the CoP can facilitate effective problem solving, practice improvement and self-renewal (Wenger, 1998; Wenger and Snyder, 2000; Wenger, McDermott and Snyder, 2002).

In the following sections, we describe the case organisation. We then detail our collaborative action research design and evaluate the founding of the $\mathrm{CoP}$ in terms of its membership, attendance, participation and outputs. Note that the sponsoring organisation did not have specific outcome metrics in advance of this intervention, and we elaborate on this choice. In our discussion section, we begin by discussing the continuing relevance of founding structures for organisations seeking to implement a modern virtual CoP before returning to our research objective of illuminating participation dynamic with reference to SDT's three primary needs. The paper concludes with a call for further research in what is, as yet, a little understood but important aspect of organisational communities-of-practice.

\section{Method}

\subsection{The case organisation and business need.}

Hewlett Packard Enterprise Services is a major knowledge-intensive organisation employing over 50,000 globally. It provides a range of application development, infrastructure, business process 
management and other outsourced services to industrial and public sector organisations, where the capacity to deliver products and services in a fast-moving and time-sensitive world is a key differentiator. Peer visibility and connection has been a challenge, particularly in its Project Management Offices. At the beginning of the research, there was no PMO directory to verify senior management's estimate of 200 PMOs of various sizes, types and maturity levels. Conscious of the problems of low awareness and simultaneous knowledge 'stickiness' (not travelling, intelligible only to local groups) and 'leakiness' (benefitting the client but not travelling into the wider organisation) (Brown and Duguid, 1991, 2002; Szulanski, 1996; von Hippel, 1994, 1998) UK senior management and key PMO managers in HPES agreed that managerial intervention was necessary to improve peerto-peer visibility and encourage dissemination of innovative local practices across the PMO groups (Pemsel, and Wiewiora, 2013; Tsaturyan and Müller, 2015). One important aspect was that at the outset no clear success criteria or performance metrics were explicitly set out. Instead, the intervention was intended as an exploratory activity to identify whether this was feasible within the organisation, with the underlying rationale that benefits (as yet not fully defined) would emerge from such a CoP. It was acknowledged that evaluating the community at a later point in time could therefore be challenging, but this was deemed to be better than attempting to set (perhaps arbitrary) performance goals for such an uncertain endeavour. Absolute targets for the number of members were therefore not set due to the lack of a clear understanding of what 'success' would look like. Although this may appear to lack rigour, given the emergent nature of the undertaking the academics and the Company managers agreed that setting numbers at the outset without a clear rationale could be detrimental. The authors were invited to participate in a collaborative project to research and aid the initiation of an intentional virtual CoP.

A distinguishing feature of PMOs in HPES is that they are not organised as functional adhocracies (Mintzberg, 1979) or as temporary organisations like a project team. In HPES they are organised primarily using an account structure according to the customers they support, creating essentially autonomous clusters of specialised resource pools for client projects. Configurations vary: a PMO may support a single project or several; conversely a large programme may contain several PMOs. 
Reflecting the diversity of services (which may be of a narrow and localised administrative nature or supporting a broad, strategic agenda such as a change programme) staff numbers were known to vary between two and eighty. As they are adjunct to the projects they serve, the quality and speed of interactions between the PMO staff, project teams and business units are a critical factor for successful project outcomes. However, geographical proximity to the client or project team is not always possible. Many PMO employees are clustered in small groups throughout the global organisation, being reliant on the problem-solving resources of more immediate colleagues, and largely unaware of 'who knows what' or 'who knows how' beyond their local community. This multilevel and fragmented structure makes analysis difficult and we elaborate on this issue later.

The challenge of integrating and benefiting from the knowledge accumulated in independent 'cellular structures' (such as the many HPES' PMOs) is significant but as yet relatively under-researched. PMO staff have to accommodate both temporal and structural variety. They often have also to adapt their in-house methods to clients' prescribed protocols and templates, creating an array of approaches and making inter-unit practice comparison difficult. As a result, clients who fund PMOs in HPES to support their specific projects and programmes tend to benefit from any project productivity improvement ahead of HPES because of the difficulty of transferring improvements internally across the organisation.

\subsection{Collaborative Action Research (CAR)}

Our team comprised academics with prior industry experience and who are actively engaged with business-related research. The CAR process used for the study is in line with Susman and Everard (1978) and Baskerville and Wood-Harper's (1996) canonical steps of diagnosis, action-planning, action-taking, evaluating and specifying learning. Actual duration and research activities of each phase are shown in Figure 1 below. 


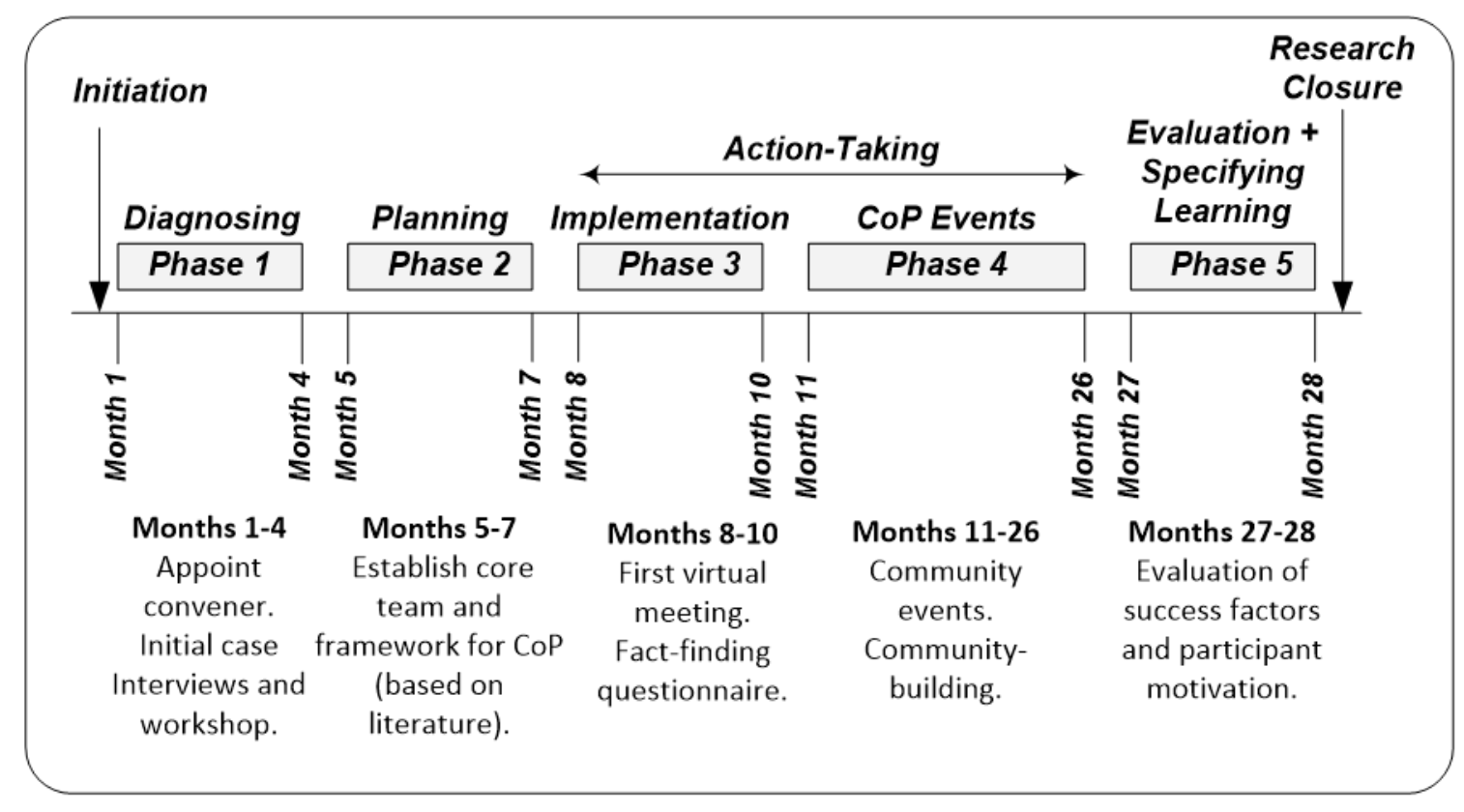

Figure 1 - The Collaborative Action Research Process

Data were collected over two years from an initial open workshop, two rounds of qualitative, factfinding and status questionnaires, twelve field visits, in-depth interviews with members of each of the eight account groups in the study, direct observation at all the CoP events, and finally five additional interviews with senior managers who commissioned the research and documentary reviews. Although the phases of the study appear sequential, research activities were iterative within each phase and in according with good CAR practice, findings were reported and presented to participants using various means throughout the research.

Our task at diagnosis was to understand the extent of isolation and connection issues experienced by the PMO employees. This was achieved through: a) a major workshop at our University with participants from across the globe, b) a series of face-to-face interviews of PMO staff from eight key HPES accounts and c) a 'getting to know you' fact-finding questionnaire to establish basic information on HPES' PMOs such as the number, size, location and nature of their work. Together, these provided us with a rich picture of the state 'as was' that had not been previously available to the organisation. 
Two questions underlined the action-planning phase: 'How do we define the purposeful CoP?' and 'What are the aims, objectives and conditions for its formation?' We reviewed the extant literature to ascertain how the CoP could be understood in this environment and derived a working definition that encapsulated the intent and purpose of a virtual CoP (provided above). Articles examined ranged from early situated-learning conceptualisations by the likes of Lave and Wenger (1991), Wenger (1998) and Brown and Duguid $(1991,1998)$ to more recent expositions accounting for the dispersed, nonsituated context (e.g. Lindkvist, 2005; Ma and Agarwal, 2007; Pan and Leidner, 2003; Silva, Goel and Mousavidin, 2009). Wenger's (1998) monuments, instruments and points-of-focus and Thompson's (2005) seeding and controlling structures provided useful guidance for question 2. Being virtual the CoP does not have a physical presence in terms of buildings or offices but it does have tangible seeding properties by way of an explicit Mission Statement (MS) and Terms of Reference (ToR), including a list of canvassed topics around which $\mathrm{CoP}$ speakers are organised. Again, we emphasise that these (shown in Appendices A and B) do not contain explicit performance targets - improved performance was anticipated to be a consequence of greater connectivity between staff. A central aspect of the CoP was to be the monthly webcasts on issues valuable to the members, so technology occupies a central role in a virtual $\mathrm{CoP}$ to support online and offline interactions. Examples include the company's web-based meeting and recording facility, a LinkedIn networking forum and HPES' 'Knowledge Center' Recording of online events was done to provide access to members who could not attend a meeting or others who wanted to remind themselves at a later date of all or certain aspects of a prior meeting. Regulatory objects by way of meeting rules and specific agendas served as pointsof-focus as well as extrinsic regulation for communicative interaction (DeSouza and Precce, 2004; Silva et al, 2009).

The appointment of an experienced manager as the $\mathrm{CoP}$ convener and the formation of a (voluntary) core team were the only other formal structural components implemented by senior management to facilitate intra-organisation connection. These individuals were tasked with implementing the founding structures, marketing the $\mathrm{CoP}$, recruiting members, negotiating the key topics for online $\mathrm{CoP}$ meetings and, subsequently, facilitating the proceedings. As online discussions can be dominated by a 
small number of individuals who are presenting sessions or who are experienced in the subject matter, another role of the convener was to ensure a balance between expert-driven learning (Lave and Wenger, 1991) and peer-to-peer constructivist learning (Koliba and Gajda, 2009).

We retreated from active collaboration to a non-participatory observation role when the project entered its action-taking phase. Over the two years, our inquiry team was present at all 17 of the organised monthly events to observe the formal presentations, practice discussions, social interactions and behaviours. We were given access to all aspects of online and offline CoP-related activities and could approach the convener, the core group and individual CoP members as required. We made twelve visits to interview and collect evidence of community development at eight local accounts across the UK (e.g. Rolls Royce, UK Ministry of Defence, UK Department of Works and Pensions) over the duration of the research project. The final phases of evaluating the case $\mathrm{CoP}$ for evidence of formation and specifying participation and learning are reported below in the 'Findings' Section.

\section{Findings}

\subsection{Evaluating the CoP formation}

During the action-taking phase of our project we were able to observe, report and later evaluate the success of the intervention by reference to the key characteristics of a community-of-practice (Wenger, 1998; Wenger et al, 2000, 2002); that is, that there is a recognised domain of interest which members identify with and are committed to, and relationships are discernible between members, allowing them to engage in joint activities, share information and help each other in solving workrelated (and even personal) problems. Shared practice was recognisable by the shared resources, outputs, stories and tools and techniques evident when we evaluated the community's participation and learning.

Membership was entirely on a voluntary basis, as HPES' senior management did not wish to mandate attendance or participation. Registered members stood at 150 shortly after the first formal event and continued to rise. After the launch of the additional LinkedIn networking facility, total membership at 
the end of the two years rose to 750 . Aside from the EMEA, around $30 \%$ of the members were from the Americas and 10\% from Asia Pacific regions. Reflecting the diversity of titles and roles in the organisation, 68\% identified themselves as 'PMO Manager', 21\% as 'PMO Member' or 'Subject Matter Expert' and 11\% were performing a project or programme management role within their respective PMOs. Time difference was a real challenge for scheduling the monthly hour-long meetings. Despite holding them at 14:00 or 15:00 GMT to encourage participation by Europe and the Americas, it was still a problem for Asia-Pacific members. In addition, nearly $40 \%$ of the membership when polled by the convener also indicated that calendar conflicts from client commitments were often barriers against participation. Nonetheless, evidence of real interest lies in the average number attending each event (rising from 30 to $>50$ ) and staying on through the open voice and messaging Q\&A session. Topic discussions were fully intelligible between the recipients and discussant right from the first meeting, indicating common professional language and understanding. Early meeting topics covering key PMO tools and techniques were rated highly. Conversation flow became more and more fluid over time with only occasional intervention by the convening team to help develop a particular line of inquiry. As membership grew and numbers attending increased, sensitive management of turn-taking and Q\&A by the core team was necessary to avoid people losing interest and leaving the meeting when they had taken time out from their busy schedules to join the conversation.

At the time of writing, the $\mathrm{CoP}$ was still in existence with a growing membership. An early conclusion is that contrary to Robert's (2006) disquiet about the deliberate formation of CoPs, it is possible to sponsor such a community. This in itself is a significant finding given the early worries by both senior management and the research team about the feasibility of the intervention. See Table 1 below for evidence of $\mathrm{CoP}$ development.

\begin{tabular}{|l|l|}
\hline Wenger's (1998) Indicators of CoP Formation & Example Observations from the Study \\
\hline \hline Customary manner of interaction & Decreased formality at events - meetings \\
\hline
\end{tabular}




\begin{tabular}{|c|c|}
\hline & $\begin{array}{l}\text { started quickly with reducing need for } \\
\text { extended introduction }\end{array}$ \\
\hline Shared styles and discourses & $\begin{array}{l}\text { Reduced need for the convener to remind } \\
\text { people of the protocols. More spontaneous } \\
\text { Q\&A sessions. }\end{array}$ \\
\hline On-going participative activities & $\begin{array}{l}\text { People swapping 'war-stories' and tips for } \\
\text { dealing with 'difficult' clients. }\end{array}$ \\
\hline Mutual relationships & $\begin{array}{l}\text { Members confirmed that relationships built } \\
\text { online were maintained offline. }\end{array}$ \\
\hline Personal identification with the group & $\begin{array}{l}\text { Members interviewed saw themselves as part } \\
\text { of a professional community and were keen } \\
\text { to align their local practices with the wider } \\
\text { community. }\end{array}$ \\
\hline $\begin{array}{l}\text { Continuous and conspicuous shared } \\
\text { repertoire }\end{array}$ & $\begin{array}{l}\text { Members involved in similar tasks or sharing } \\
\text { interests would seek help and advice from } \\
\text { one another, and then bring the learning and } \\
\text { improvement to subsequent meetings. }\end{array}$ \\
\hline
\end{tabular}

\section{Table 1 Evidence as a Community}

To ascertain the motivations of the participants and their perceptions of the benefits of the CoP, the convener and the research team polled the members during the action-taking phase. This was intended as a simple method of determining the status of the CoP and whether the participants believed any changes should be initiated, but the results were in line with our qualitative interviews. Of the 68 who responded, to the question 'What types of contributions has the CoP made to date?', $90 \%$ said 'Improving organizational performance', 90\% 'Helping individual and group development' and 88\% 'Enhancing the recognition and development of the role of PMOs'. To the question 'What is your motivation for being part of the CoP?', $88 \%$ said 'Finding best practices from other PMOs', $85 \%$ 'Exchanging knowledge' and $84 \%$ 'Finding out what is going on'. When asked 'How has the participation in the CoP helped you?', 69\% said 'Greater awareness of expertise within the organisation' and $68 \%$ 'Increased knowledge to apply to the job'. Other options received notably fewer responses. 


\subsection{Discernible relationships and joint activities.}

Our analysis of interactions also revealed three distinct groupings of collaborative interaction; each capable of producing its own embodied forms of practice. Figure 2 illustrates in diagrammatic form the clusters of association by workers in their daily work and social routines. The level, purpose and extent of socialisation could be analysed with reference to the definitional differences between communities-, collectivities- and networks-of-practice.

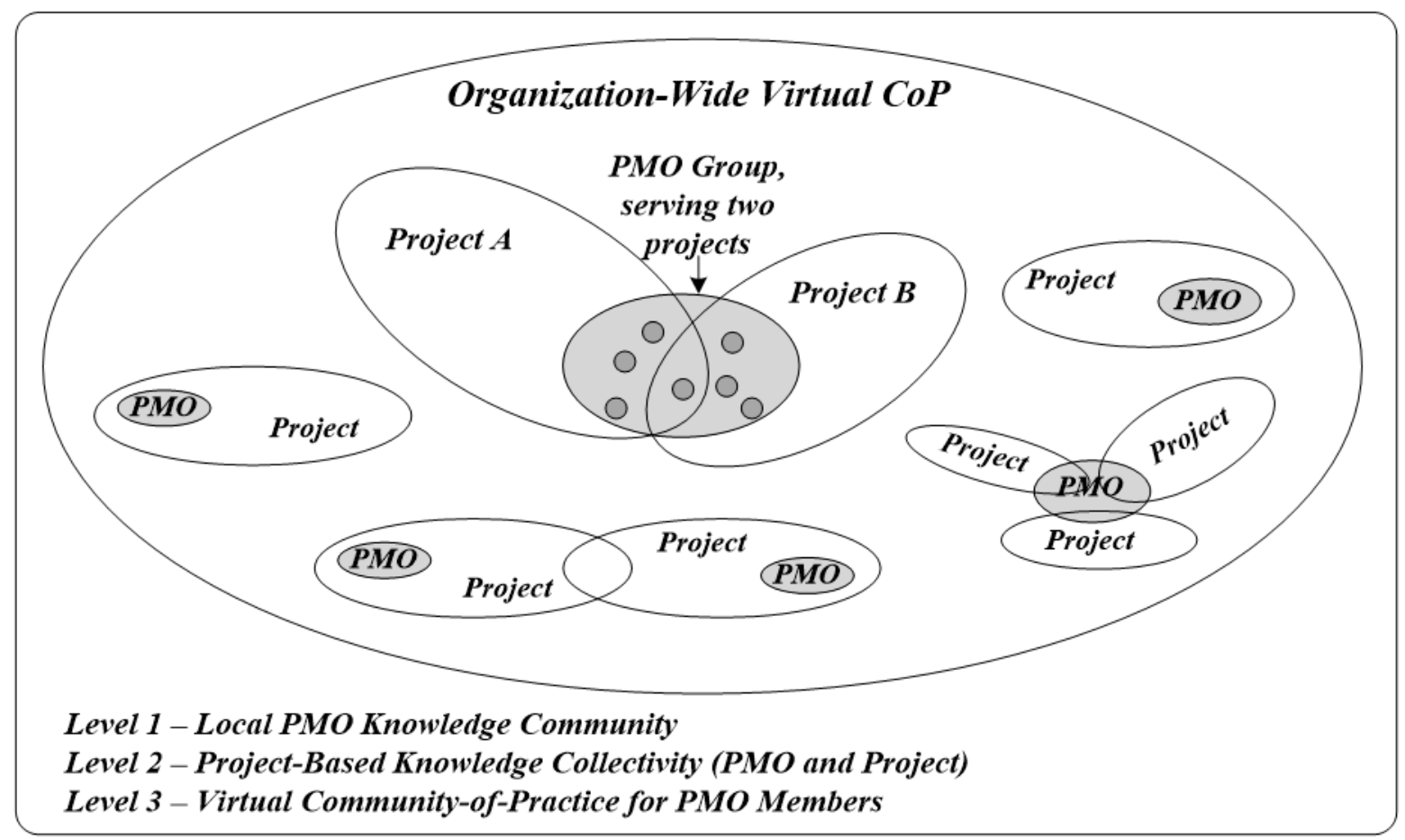

Figure 2 - Multiple Associations

The first level of association is at the local PMO community. Close proximity and repeated interactions gave rise to much of the characteristics found in traditional communities such as high trust, shared routines, a common language and strong shared cognitions. The case PMOs are defined by their geography (i.e. physical location, such as a site or town/city) rather than by hierarchy or technical specialism. The client-account orientation in the PMOs means that technical, clientrelationship and administrative representatives can collaborate closely to draw and share lessons from their involvement not only in projects, but also with other account groups. We sat in on a number of 
local meetings and the atmosphere and exchanges in the office and during the meetings could be described as highly social, relaxed and free-flowing. Minutes of meetings corroborated explanations by individuals that conversations are centered on satisfying client needs through relationship management and service improvements (including ways of marketing next-generation offerings to their clients) - thus fulfilling much of Wenger's (1998) community criteria of mutual engagement, joint enterprise and shared repertoire.

A second level of association exists for PMO workers when assigned to support projects. Often continuing to work from their local office or from home, they tend to communicate electronically or over the telephone with the core delivery team. These groups of virtually seconded PMO personnel exhibit much of the collectivity characteristics described by Lindvist (2005) in their interactions with project teams. As individuals, the PMO and project workers are professionally related as a resource for the project and share the common goal of bringing about its successful outcome (Boland and Tenkasi, 1995). They also share a practice narrative with the project teams which makes distanced communication easier as it allows the articulation and probing of 'in-situ' (not necessarily situated) practice problems. However, geographical distance, temporal separation and temporary association in these project collectivities restricted the high socialisation and development of a common 'blackboard' memory of complex and ambiguous knowledge characteristics of a classical knowledge community. As anticipated by Lindkvist (2005) the root property of these level-2 collectivities is professional commitment rather than strong social bonds. Interactions were instrumental and as a means of "finding best practice" and searching for "increased knowledge to apply to the job". The sort of interpersonal affect-laden social relations anticipated by Etzioni (1996) were more noticeable between knowledgeable agents back in the local communities.

A third level of association for the case participants is the wider organisational CoP, which draws its membership primarily from the constellations of PMO knowledge communities. As people 'learned' to become a part of the virtual COP (“...developed a feeling of belonging to a group of similar professionals - makes us feel part of something") they were keen to align their local practices with 
the wider community ("so as not to reinvent the wheel"; "more efficient way of working'; "why didn't we do this before?").

\subsection{Specifying Participation and Learning}

Participation was tentative at the beginning, led largely by the convener and core group, and individual connection strategy was mostly about information gathering. The common theme from the interim status questionnaire revealed an inherent desire for peer-to-peer connection ("centralised contacts"; "single point of contact"; "a communication channel") driven by the need for information and work-specific knowledge ("relevant knowledge and practices"; "access to expertise"; "issues related to PMO work and management"; "unification of processes").

Over the course of the study we observed an epistemological shift in the presentations and exchanges. We sought to identify the nature of the knowledge of primary interest to the participants, and drew on key literature in this respect. Both tacit and explicit knowledge was discussed among the community (Nonaka, 1994; Polanyi, 1957). Although the primary purpose of this may be deemed as exploitation (March, 1991), since effective practices and ideas were being shared and refined, the trials of the ideas in new contexts to test their effectiveness can also be viewed as exploration. This leads to an important understanding from a knowledge perspective of how both can be accommodated in a project environment (Turner et al., 2015).

We used the work of Wang and Ramiller (2009) in our analysis. In looking at community learning in information technology innovation, they utilise previous theorisations (Bohn, 1994; Garud, 1997; Hamel, 2006; Lundvall and Johnson, 1994; Swanson and Ramiller, 2004). They identify the following knowledge forms in this context:

"Know-what: interpretations of the principles, features, or components of the innovation;

Know-why: rationales for the adoption of the innovation; Know-how: strategies/capabilities for adopting, implementing, or assimilating the innovation." (Wang and Ramiller, 2009:717) 
Although the overall model they develop is complex, these forms are noteworthy in that we observed a transition over time through the three. Whereas initial meetings focused largely about the 'knowhow' such as subjects on risk management and use of PMO toolkits, this transitioned into expanding participants' knowledge exampled by 'know-what' topics covering project complexity, PMO operating models and updates on the profession itself. The final mode observed was the increasing interest on 'knowing-why'. Instead of just focusing on their specific spheres of interest, individuals were actively seeking to learn more about wider organisational and operational developments such as HPES' strategy and approach to organisational learning, what governance models were in place or being implemented to improve performance and the strategic challenges facing the organisation, their implications for the business and how it proposed to address them. We noted this from our discussions with $\mathrm{CoP}$ members and it was confirmed by the convener, who also noticed that the nature of the discussions and the requests for topic areas moved significantly over the period of the study. Conversations transitioned over time from the tactical to more nuanced, in-depth discussions.

Table 3 shows examples of these evolving knowledge interests.

\begin{tabular}{|c|c|c|}
\hline $\begin{array}{l}\text { Knowledge } \\
\text { Type }\end{array}$ & Description & Examples of Community Events \\
\hline 'Know-How' & $\begin{array}{l}\text { Refers to 'acts' of doing something. } \\
\text { Suitable for direct or immediate } \\
\text { applications for quick improvements. }\end{array}$ & $\begin{array}{l}\text { Organisational Tools and Techniques. } \\
\text { Risk Management }\end{array}$ \\
\hline $\begin{array}{l}\text { 'Know- } \\
\text { What' }\end{array}$ & $\begin{array}{l}\text { Refers to the ability to recognise } \\
\text { something needs to be done in a } \\
\text { certain or different way, which } \\
\text { would lead to the individual offering } \\
\text { organisational improvements and } \\
\text { subsequent internalisation. }\end{array}$ & $\begin{array}{l}\text { 'Managing Complexity' } \\
\text { Events on PMO models, PMOs on } \\
\text { new accounts, along with updates on } \\
\text { the profession. }\end{array}$ \\
\hline 'Know-Why' & $\begin{array}{l}\text { The highest of the three types of } \\
\text { knowledge. Individuals understand } \\
\text { why something has to be done and }\end{array}$ & $\begin{array}{l}\text { IT Governance, new targeted Task } \\
\text { Forces and initiatives, worldwide } \\
\text { work distribution strategies. }\end{array}$ \\
\hline
\end{tabular}




\begin{tabular}{|l|l|l|}
\hline & $\begin{array}{l}\text { are able to identify and weigh the } \\
\text { options to make an informed choice. }\end{array}$ & Organisational Learning \\
\hline
\end{tabular}

Table 2 - Evolving Nature of Knowledge Modes

Along with the decreasing formality at events and discussion sessions (noted above) the type and usefulness of information exchanged by members also evolved. Efforts to 'pull' information gradually gave way to extended dialogues on lessons, experiences and shared solutions.

Additionally, individuals would volunteer to conduct further discussions offline on particular issues or ideas for improvement, resulting in a number of major initiatives: (1) the development of a PMO 'Service Catalogue' (akin to a 'menu' of offerings from the organisation); (2) the setting up of a HPES-specific, cross-community 'PMO quick-start' initiative to use previous experience to create new PMOs rapidly and efficiently; (3) the formation of a lessons-learned special interest group; (4) effective uploading, sharing and dissemination of locally-created estimation, risk and other tools to a wider audience. Hence, as with our earlier conclusion that management intervention is a feasible option for initiating and enabling the formation of a 'living' virtual community, we also surmised from our analysis of the types of knowledge being shared, the feed-forward and feedback of participation and learning and actual shared outputs from the 17 events that we observed that a 'virtuous circle' (Thompson, 2005) had developed.

\section{Discussion of Findings}

\subsection{Overview}

We drew two initial conclusions from the findings, that (1) it is possible to design and form a purposeful virtual community and maintain it over a substantial period, and (2) the process of sharing tacit dimensions from the workplace for mutual problem-solving and learning (once a characteristic of situated learning - Lave and Wenger, 1991) can also flourish in a virtual setting. They imply a successful intervention that is ongoing. Here, we discuss our findings and their implications with reference to the structural components for community formation and their role in the modern, 
distributed CoP. We then discuss why, important as they are, the foundational structures cannot really explain the reasons for active and enduring participation, requiring instead a strong appreciation by companies of the complex motivations underscoring individual action and behaviour.

Reflecting on the CoP project for lessons from its formation, we found the collaborative action research process was significant in ensuring a strong understanding of the issues and needs of the organisation and employees upon which the CoP's objectives and its foundational structures were based. Briefly, a rich picture of the state 'as was' emerged from the initial diagnosis phase, helping researchers and management understand the extent of the isolation problem faced by dispersed PMO employees. The second action-planning phase reviewed the extant literature to help define the purposeful CoP, frame its aims and objectives, set the conditions for formation and select the technical platforms for synchronous and asynchronous communication. The ability of the appointed convener and his team to manage pace and turn-taking in meetings is critical for individual perspective-taking and balancing between expert-driven learning (Lave and Wenger, 1991) and peerto-peer constructivist learning (Koliba and Gajda, 2009). This suggests that when contemplating an intervention to connect dispersed employees, senior management must be willing to invest in the requisite structures that will bridge the distance gap, and raise inter-member visibility and accessibility. Consideration must also be given to the process of understanding, formulating and communicating the purpose and objectives of the intervention.

Central to the story of building a purposeful virtual CoP is why dispersed and busy people would respond positively to organised events. In Thompson's (2005) view, founding structures are 'the easy part' (p151) as people have still to be convinced to interact with the structures and to connect with others from the community. The self-determined nature of CoP participation is significant. Not everyone will wish to participate fully and there are also many forms of participation (e.g. as masters or novices) (Wenger, 1998). Similarly, the concepts of legitimacy and periphery (Lave and Wenger, 1991) remind us that perception is a critical determinant of participation. In other words, HPES may have provided its PMO employees with the means to connect but member reports of time zone 
differences, workload and diary clashes, perceived low management support and constant negotiation and renegotiation between PMO workers and project teams, could have distorted or limited the motivation to participate in the purposeful CoP. Yet, without the need of coercion or explicit incentive, many of the PMO employees were motivated sufficiently to join the CoP, attend events and interact actively. We recorded growing attendance at monthly meetings, identified evolving sophistication of knowledge modes, witnessed the voluntary sharing of 'best-practice' templates and approaches and wider dissemination of information and ideas to other local PMOs and project colleagues, including their use directly in support of client accounts. The resultant co-generation of client- and task-oriented solutions gained through membership of a particular social group are the very kind of shared tacit knowledge and tangible outputs that can reduce the problems of knowledge 'stickiness' and 'leakiness' experienced by companies.

Although Thompson's (2005) research on structural parameters identified the need for a culturally symbolic infrastructure (p162) to support perspective-taking he did not elaborate individual responses to external barriers or stimuli. This project adds to the literature by exploring the practical implications of $\mathrm{CoP}$ participation with reference to three psychological needs for self-determined action: the need for autonomy, competency and belonging.

\subsection{Autonomy}

Autonomy and choice ability are grounded in self-determination theory (Deci and Ryan, 1985; Ryan and Deci, 1985). Referring to the capacity for self-initiatied action and decision, autonomy and choice are fundamental behaviour regulators. Founding structures are subject to the perceived degree to which people are allowed or restricted autonomous action and that this can affect the quality and quantity of interaction. We also noted the tension between senior management's desire for wider intra-organisation exchange and staff perceptions of low management support. Notably, despite this perceived lack of support, study evidence (the CoP's terms of reference states that membership is voluntary) reinforces senior management's commitment to preserving the autonomy value of the intervention. The company has also refrained from offering any contingent incentive, threat of 
punishment or expectation of measured outcomes from the investment (e.g. return on investment or project profitability). This is significant for practice because contingent rewards as external control levers can actually reduce intrinsic motivation (Deci, Koestner and Ryan, 1999). Feedback has been positive as regards the lack of compulsion or coercion, although the general feeling is that the organisation could do more to facilitate participation - "line management should schedule time for CoP activities". Another important insight is the observed multiple associations. They suggest that a contributory factor to CoP success is to ensure individuals retain the personal freedom to decide their own socialisation strategy. Rather than seeking to pressurise people into joining, HPES' voluntary approach has helped engender a more affective and enduring commitment to the CoP - "I always join in when I can" and "It's become my first port of call" - thus supporting the notion of autonomy as a key element for consideration in purposeful CoPs.

\subsection{Competence}

Competence is critical for task performance especially in knowledge intensive organisations such as HPES. It is clear from our study that the motives for engagement in the early stages of the CoP were about information-seeking and task or role related - "finding out what is going on" and "helps me do my job better". Events hosted by invited specialist speakers were particularly well attended $(>50)$ by members conscious of the need to reduce practice duplication and the value of more efficient or effective work-based solutions - "greater awareness of expertise within the organisation" and "increased knowledge to apply to the job". Interactions within the local communities, work collectivities and wider intra-organisational networks also suggest that information and knowledge are perceived and valued differently. Starting with the literature assumption that an autonomy-supportive environment is desirable to facilitate knowledge exchange and worker self-development, the practical implication here is the capacity of the CoP to provide for individual competency needs. In the case of this CoP, HPES employs a broad a range of communication and knowledge management technologies to support online and offline exchange and retrieval. This is in line with self-determination theory's thesis that the willingness to invest in pro-social activity is related to the extent to which the mix of intrinsic and extrinsic regulators can help individuals acquire valued skills and to attain personal 
goals. Indeed, as members became aware of who-knows-what-and-how, they also started to identify with the bigger organisation goals - "better understanding of where the organisation is going and why". This implies that the plan for a purposeful CoP, and its evolution over time, would benefit from including considerations of its function, legitimacy and centrality in relation to other existing intraorganisation connections.

\subsection{Sense of Belonging and Relatedness}

The need to belong and a sense of identity is particularly relevant for PMO personnel because of their global distribution, lack of a distinct job code for their function and a staff directory to locate similar others. In our study, members quickly saw themselves as part of a professional community, typically because "it's good to be seen, to belong and be more visible in the organisation". The idea of building up one's professional reputation was a common theme. What is instructive here is the adaptive behaviours of members. Without any deliberate changes to the structure, meeting or communication processes, participative behaviour regulation was becoming more self-regulatory and intrinsically autonomous. Members who find CoP activities intrinsically interesting and beneficial are willing to be more altruistic in their sharing behaviour and participation becomes an integral part of their social routine. This is evidenced by the practice of swapping 'war-stories', and tips for clientmanagement became a regular feature following a session when someone chose to share his story about a difficult client and inviting suggestions on how to improve that relationship. Discussions also took place openly about career prospects especially when a major sponsor stopped funding a particular PMO, leaving individuals vulnerable and in need of a transfer to another office. Gagné and Deci (2005) call this phenomenon 'identified regulation' (p334) where pro-social behaviours are seen as congruent with individual goals. Another important benefit from the intervention is an expanding personal network of associations. We have been able to ascertain from our findings that the intervention has enabled dispersed and often isolated individuals the opportunity to relate and belong. The relatedness through relationships built within the virtual $\mathrm{CoP}$ are often maintained beyond the $\mathrm{CoP}$ to the wider organisation, particularly those from a similar technical discipline or who shared a common client - "making new connections with others in the organisation". The change of 
knowledge modes over the 17 events we studied also indicates that members were really beginning to value the $\mathrm{CoP}$ and saw it as the natural place for information, knowledge, ideas and social identity. The practical implication of belonging and relatedness lies in the potential for a purposeful CoP to engender a sense of identity, increase organisational commitment and reduce staff attrition, and these ideas came through clearly in our interviews.

\subsection{Participation - Non-Participation, a Continuum}

At the situational task level, the harder the task, the more important the key knowledge is for performance, yet despite the apparent success of the intervention CoP project and its potential for meeting the psychological needs of many, a number of PMO workers have refrained from joining the CoP for reasons unknown. SDT views motivation as a continuum, from amotivation to controlled to autonomous. The lowest level of self-determination is amotivation which has an impersonal locus of causality (Deci and Ryan, 2000) and this has implications for HPES. Perhaps people who have not joined or participated do not see the relevance of the $\mathrm{CoP}$ and are not interested in engaging in the activity. Fortunately, just as people can have different amounts and different motivation orientations, motivation in SDT is also dynamic and can change with individuals' perceptions of their personal circumstances and task-environment. The challenge for organisations is to manage the mix of controlled and autonomous motivation, to increase membership and participation without affecting negatively the perception and willingness of existing members to continue their contribution. Although SDT is adamant about the superiority of autonomy over externally imposed structures, the legitimisation of the $\mathrm{CoP}$ as an intervention project has been critical for promoting and maintaining participation. Viewing themselves as more of an enlightened than a controlling agent (Wenger and Synder, 2000), senior management have, so far, avoided imposing formalised structures to censor and monitor CoP activities and attendance, preferring to rely instead on the MS, ToR and the convener and his team to guide behaviour and achievement. This approach was adopted initially because of the low state of knowledge regarding potential members and the appreciation that PMO personnel are in a better position to provide examples of best-practice and to know any gaps in skills that need addressing, thus leading to more relevant and valued learning. By limiting the remit of the convener 
and his core team to be largely administrative, and allowing voluntary membership and participation, senior management demonstrated their light-touch approach, avoiding the threat of over-control and loss of choice. Ironically, such an informal strategy was misinterpreted as a lack of commitment by members struggling to make time to engage in $\mathrm{CoP}$ activities. To avoid the $\mathrm{CoP}$ losing its appeal and relevance, line managers (backed by senior management) must recognise that effort is required to sustain the CoP and allow members greater flexibility over their work schedule for CoP activities.

\subsection{Evaluation of Success}

As discussed, the original intention of the intervention was to use the CoP activities as enablers that would lead to superior organisational performance, notwithstanding that the exact mechanisms by which this would occur were not clear at the outset. Evaluation of the $\mathrm{CoP}$ is therefore necessarily subjective. Interviews with five senior executives (three operational and two corporate) indicated that they were pleased with how the CoP was structured and implemented and were, as one said, "very impressed with the number of attendees and how well numbers [of participants] have sustained over time" and with the "relevance and quality of the event content." With regard to the attendees and those engaged online, the perception was positive both in terms of numbers but also of the longevity of the engagement, as the CoP may have withered after only a few meetings.

It is not practicable to link the development of the CoP to financial metrics, and indeed the organisation has not attempted this. However, indications from members are that knowledge-sharing has resulted in a myriad of incremental improvements in practice that are perceived to have improved overall performance. Many also confirmed that the CoP has become an important source of PMO contacts and that their new connections helped them solve problems and develop tools that they are able to share locally. The value of the increase in employee engagement resulting from participation in the CoP must also be considered. The fact that busy staff choose to engage is also a strong indicator that they find it worthwhile. The presence of the $\mathrm{CoP}$ has also contributed to the recognition across the organisation that the PMO groups perform an important function within the organisation, as well 
as for client accounts. It is also generally seen by members, managers, and senior executives as an important vehicle for getting connected and enabling the roll-out of new capabilities and practices.

\section{Conclusion}

We have shown insights from the individual viewpoint on the drivers for knowledge sharing by experienced professionals in key support functions of major initiatives who are not novices and do not have to earn the right of passage from the periphery, an unusual perspective. We found complex multi-level motivations for interactions where sharing and learning activities were grounded in the recognised need for competence and renewal, together with opportunity for recognition by significant others. For global KIOs such as our case organisation, the value of the intentional, virtual, CoP is as a mechanism for integrating knowledge from the dispersed populations of knowledge communities. In this context, technology is a key structural component to support discursive practice (stories, debates and shared diagnoses) and as a repository for multi-media communal memory.

Our contributions are that we have increased our understanding of individual drivers for discursive participation and the merits of joining the conversation on practice at a distance. Individuals seek personal growth, new skills and reputation enhancement, within both a context of their local knowledge community that seeks new capabilities, and their (project-based) collectivity which needs in-situ, real-time, effective problem-solving. Member motivation is initially for finding best practices, exchanging knowledge and finding out 'what is going on' in the wider community, and these needs were perceived to have been met. This was, though, not static. Our findings show that the epistemological motivations appear to shift from 'know-what' towards 'know-why' as the community matures, despite the continuous influx of new participants.

We note that the CoP has met the top-down needs of the senior management who sanctioned and sponsored its initiation, and the bottom-up desires of the members. Facilitation by the convener and his core team to guide the CoP agenda over time appears instrumental in meeting these twin requirements. The ready availability of technology infrastructure is a necessary, but not sufficient, 
aspect of community-building. We draw on the seeding and controlling structures of Thompson (2005) and find that these can also aid in member motivation through allowing 'easier' access to the community, an important aspect for busy professionals. Using Wenger's (1998) indicators, we identified that the CoP did indeed form, despite its complex nature.

This work can be continued to add value for both scholars and practitioners. By following this case further and generating data from additional cases, greater insight can be obtained as to the nature of the evolution and the identification of success factors within such multi-level, distributed, CoPs. This could include investigation of the structural issues and their relationship to the members' motivation, which appears to be a fruitful area of inquiry.

\section{References}

1. Agterberg, M., van den Hooff, B., Huysmann, M. and Soekijad, M., 2009. Keeping the wheels turning: the dynamics of managing networks of practice. Journal of Management Studies, 47(1), 85-108.

2. Ahern, T., Leavy, B. and Byrne, P.J., 2014. Knowledge formation and learning in the management of projects: A problem solving perspective. International Journal of Project Management, 32(8), 1423-1431.

3. Ahuja, G., 2000. Collaboration networks, structural holes and innovation: a longitudinal study. Administrative Science Quarterly, 45, 425-455.

4. Ajzen, I., 1991. The theory of planned behavior. Organizational Behavior and Human Decision Processes, 50(2), 179-211.

5. Ajzen, I. and Fishbei, M., 1980. Understanding attitudes and predicting social behavior. Englewood Cliffs, NJ: Prentice Hall.

6. Amin, A. and Roberts, J., 2008. Knowing in action: beyond communities of practice. Research Policy, 37, 353-369.

7. Argote, L. and Ingram, P., 2000. Knowledge transfer: a basis for competitive advantage in firms. Organizational Behavior and Human Decision, 82, 150-169

8. Argote, L., McEvily, B. and Reagans, R., 2003. Managing knowledge in organizations: an integrative framework and review of emerging themes. Management Science, 49, 571-582.

9. Arthur M.B., DeFillippi R. J. and Jones C., 2001. Project-based learning as the interplay of career and company non-financial capital. Management Learning 32(1): 99-117.

10. Artto, K., Kulvik, I., Poskela, J. and Turkulainen, V., 2011. The integrative role of the project management office in the front end of innovation. International Journal of Project Management. 29 (4), 408-421.

11. Ayas K. and Zeniuk N., 2001. Project-based learning: Building communities of reflective practitioners. Management Learning 32(1): 61-77. 
12. Bandura A., 1982. Self-efficacy mechanism in human agency. American Psychologist, 37, 122-147.

13. Bandura, A. 1997. Self-efficacy: The exercise of control. New York: Freeman.

14. Bartsch, V., Ebers, M. and Maurer, I., 2013. Learning in project-based organizations: The role of project teams' social capital for overcoming barriers to learning. International Journal of Project Management. 31(2), 239-251.

15. Baskerville, R. L., and Wood-Harper, A. T., 1996. A critical perspective on action research as a method for information systems research. Journal of Information Technology, 11(3), 235246

16. Baumeister, R. F., and Leary, M. R., 1995. The need to belong: desire for interpersonal attachments as a fundamental human motivation. Psychological Bulletin, 117(3), 497.

17. Bell, C., and Newby, H., 1974. The sociology of community: A selection of readings. London:

18. Boland, R. and Tenkasi, R., 1995. Perspective making and perspective taking in communities of knowing. Organization Science, 6(4), 350-372.

19. Bosch-Sijtsema, P.M. and Henriksson, L-H., 2014. Managing projects with distributed and embedded knowledge through interactions. International Journal of Project Management. 32(8), 1432-1444.

20. Brady T. and Davies A., 2004. Building project capabilities: From exploratory to exploitative learning. Organization Studies 25(9): 1601-1621.

21. Brodbeck, F.C., Kerschreiter, R., Mojzisch, A. and Schulz-Hardt, S., 2007. Group decision making under conditions of distributed knowledge: the information asymmetries model. Academy of Management Review, 32, 459-479.

22. Brown, J. S. and Duguid, P., 1991. Organizational learning and communities-of-practice: toward a unified view of working, learning and innovation. Organization Science, 2(1), 4057.

23. Brown, J. S. and Duguid, P., 1998. Organizing knowledge. California Management Review, 40(3), 90-111.

24. Brown, J. S., and Duguid, P., 2001. Knowledge and organization: a social-practice perspective. Organization Science, 12(2), 198-213.

25. Brown, J. S. and Duguid, P., 2002. Local knowledge. Innovation in the networked age. Management Learning, 33(4), 427-437.

26. Cacciatori E, Tamoschus D and Grabher G., 2012. Knowledge transfer across projects: Codification in creative, high-tech and engineering industries. Management Learning 43(3): 309-331.

27. Carrillo, P., Ruikar, K. and Fuller, P., 2013. When will we learn? Improving lessons learned practice in construction. International Journal of Project Management. 31(4), 567-578.

28. Charalambos, V., Machalinos, Z., and Chamberlain, R., 2004. The design of online learning communities: critical issues. Education Media International, ISSN 469-5790 online http://www.tandf.co.uk/journals

29. Chiu, C-M., Hsu M-H and Wang, E.T.G., 2006. Understanding knowledge sharing in virtual communities: an integration of social capital and social cognitive theories, Decision Support Systems, 42, 1872-1888.

30. Cho, H-C., Chen, M-H, and Chung, S-Y., 2010. Testing an integrative model of knowledge sharing behavior in the context of Wikipedia. Journal of American Society for Information Science and Technology, 61(6), 1198-1212.

31. Davies A. and Brady T., 2000. Organisational capabilities and learning in complex product systems: Towards repeatable solutions. Research Policy 29(7): 931-953. 
32. deCharms, R., 1968. Personal causations: the internal affective determinants of behavior. New York: Academic Press.

33. Deci, E. L., Koestner, R., and Ryan, R. M., 1999. A meta-analytic review of experiments examining the effects of extrinsic rewards on intrinsic. Psychological Bulletin, 125(6), 627.

34. Deci, E.L. and Ryan, R.M., 1985. Intrinsic motivation and self-determination in human behavior. New York: Plenum.

35. Deci, E.L. and Ryan, R.M., 2000. The 'what' and why' of goal pursuits: human needs and the self-determination of behavior, Psychological Inquiry, 11(4): 227-268.

36. De Dreu C.K.W., Nijstad, B. and van Knippenberg, D., 2008. Motivated information processing in group judgment and decision making. Personality and Social Psychology Review, 12, 22-49.

37. De Souza, C. S., and Preece, J., 2004. A framework for analyzing and understanding online communities. Interacting with Computers, 16(3), 579-610.

38. Di Vincenzo, F. and Mascia, D., 2012. Social capital in project-based organizations: Its role, structure, and impact on project performance. International Journal of Project Management. $30(1), 5-14$.

39. Duffield, S. and Whitty, S.J., 2016. How to apply the Systemic Lessons Learned Knowledge model to wire an organisation for the capability of storytelling. International Journal of Project Management. 34(3), 429-443.

40. Dutton, C., Turner, N. and Lee-Kelley, L., 2014. Learning in a programme context: An exploratory investigation of drivers and constraints. International Journal of Project Management. 32(5), 747-758.

41. Enberg C, Lindkvist L and Tell F., 2006. Exploring the dynamics of knowledge integration: Acting and interacting in project teams. Management Learning 37(2): 143-165.

42. Eriksson, P., 2013. Exploration and exploitation in project-based organizations: Development and diffusion of knowledge at different organizational levels in construction companies. International Journal of Project Management. 31(3), 333-341.

43. Etzioni, A., 1996. The responsive community: a communitarian perspective. American Sociological Review, 61(1), 1-11.

44. Fernandes, G., Ward, S. and Araújo, M., 2015. Improving and embedding project management practice in organisations - A qualitative study. International Journal of Project Management, 33(5), 1052-1067.

45. Fischer, G., 2001. Communities of interest: learning through the interaction of multiple knowledge systems. $24^{\text {th }}$ Annual Information Systems Research Seminar in Scandinavia, Bergen, Norway. Department of information science.

46. Gagné, M., 2009. A model of knowledge-sharing motivation. Human Resource Management, 48(4), 571-589.

47. Gagné, M., and Deci, E. L., 2005. Self-determination theory and work motivation. Journal of Organizational Behavior, 26(4), 331-362.

48. Galbraith, J. R., 1994. Competing with flexible lateral organizations. Reading, MA: Addison Wesley.

49. Garud, R. 1997. "On the Distinction between Know-How, Know-What, and Know-Why," in Organizational Learning and Strategic Management: Advances in Strategic Management, J.P. Walsh and A. S. Huff (eds.), Greenwich CT: JAI Press, 81-101.

50. Geraldi J. G., Kutsch E. and Turner N., 2011. Towards a conceptualisation of quality in information technology projects. International Journal of Project Management 29(5): 557567.

51. Gilson, L.; Maynard, M.T., Jones Young, N.C., Vartiainen, M. and Hakonen, M., 2015. Virtual Teams Research: 10 Years, 10 Themes, and 10 Opportunities. Journal of Management, 41(5), 1313-1337

52. Gittelman, M., 2007.Does geography matter for science-based firms? Epistemic communities 
and the geography of research and patenting in biotechnology. Organization Science 18, 724 741

53. Gherardi, S., 2006. Organizational knowledge: the texture of workplace learning. Oxford, Blackwell.

54. Gherardi, S. and Nicolini, D., 2000. The organizational learning of safety in communities of practice. Journal of Management Inquiry, 9(1), 7-18

55. Gherardi, S. and Nicolini, D., 2002. Learning in a constellation of interconnected practices: cannon or dissonance? Journal of Management Studies, 39(4), 419-436.

56. Grant, R.M., 1996. Toward a knowledge-based theory of the firm. Strategic Management Journal, 17(10), 109-122.

57. Gray, B., 2004. Informal learning in an online community of practice, Journal of Distance Education, 19(1), 20-35.

58. Hamel, G. 2006. The Why, What, and How of Management Innovation, Harvard Business Review, 84(2), pp. 72-84

59. Han, J. and Hovav, A., 2013. To bridge or to bond? Diverse social connections in an IS project team. International Journal of Project Management. 31(3), 378-390.

60. Handley, K., Sturdy, A., Fincham, T. and Clark, T., 2006. Within and beyond communities of practice: making sense of learning through participation, identity and practice, Journal of Management Studies, 43(3), 641-653.

61. He, W. and Wei K-K., 2009. What drives continued knowledge sharing? An investigation of knowledge-contribution and -seeking beliefs, Decision Support Systems, 46, 826-838.

62. Holzmann, V., 2013. A meta-analysis of brokering knowledge in project management. International Journal of Project Management. 31(1), 2-13.

63. Julian, J., 2008. How project management office leaders facilitate cross-project learning and continuous improvement. Project Management Journal 39 (3), 43-58.

64. Kalman, M.E., Monge, P., Fulk, J. and Heino, R., 2002. Motivations to resolve communication dilemmas in database-mediated collaboration. Comm. Res. 29, 125-154.

65. Keegan A. and Turner J. R. (2001) Quantity versus quality in project-based learning practices. Management Learning 32(1): 77-99.

66. Klein B. and Meckling W., 1958. Application of operations research to development decisions. Operations Research 6(3): 352-363.

67. Koliba, C. and Gajda, R., 2009. "Communities of practice" an analytical construct: implications for theory and practice. International Journal for Public Administration, 32(2), 97-135.

68. Lave, J. and Wenger, E. C., 1991. Situated learning: legitimate peripheral participation. Cambridge, UK: Cambridge University Press.

69. Lee, J., Park, J. and Lee, S., 2015. Raising team social capital with knowledge and communication in information systems development projects. International Journal of Project Management, 33(4), 797-807.

70. Lenfle S., 2008. Exploration and project management. International Journal of Project Management 26(5): 469-478.

71. Lenfle S., 2014. Toward a genealogy of project management: Sidewinder and the management of exploratory projects. International Journal of Project Management 32(6): 921-931.

72. Lenfle S. and Loch C., 2010. Lost roots: How project management came to emphasize control over flexibility and novelty. California Management Review 53(1): 32-55.

73. Lesser, E.L. and Everest, K., 2001. Using communities of practice to manage intellectual capital, Ivey Business Journal, 65(4), 37-41. 
74. Liedtka, J., 1999. Linking competitive advantage with communities of practice. Journal of Management Inquiry 8(1), 67-77

75. Lindkvist, L., 2005. Knowledge communities and knowledge collectivities: a typology of knowledge work in groups. Journal of Management Studies, 42(6), 1189-1210.

76. Liu, L. and Yetton, P., 2007. The contingent effects on project performance of conducting project reviews and deploying project management offices. IEEE Transactions on Engineering Management. 54 (4), 789-799.

77. Lundvall, B.-Å., and Johnson, B. 1994. "The Learning Economy,” Journal of Industry Studies $1(2)$, pp. 23-42.

78. Ma, M., and Agarwal, R., 2007. Through a glass darkly: Information technology design, identity verification, and knowledge contribution in online communities. Information Systems Research, 18(1), 42-67.

79. March, J.G., 1991. Exploration and exploitation in organizational learning. Organization Science 2(1), 71-87.

80. McDermott, R. and Archibald, D. 2010. Harnessing your staff's informal networks. Harvard Business Review, Mar, 88, 82-89.

81. Meeuwesen and Berends, 2007. Creating communities of practices to manage technological knowledge. European Journal of Innovation Management, 10(3), 333- 347

82. Mintzberg, H., 1979. The structuring of organizations. Englewood Cliffs, NY: Prentice Hall.

83. Nonaka, I., 1994. A dynamic theory of organizational knowledge creation. Organization Science. 5(1), 14-37.

84. Pan, S.L. and Leidner, D.E., 2003. Bridging communities of practice with information technology in pursuit of global knowledge sharing. Journal of Strategic Information Systems, 12(1), 71-88.

85. Pemsel, S. and Müller, R., 2012. The governance of knowledge in project-based organizations. International Journal of Project Management. 30(8), 865-876.

86. Pemsel, S. and Wiewiora, A., 2013. Project management office a knowledge broker in project-based organisations. International Journal of Project Management. 31(1), 31-42.

87. Pemsel, S., Wiewiora, A., Müller, R., Aubry, M. and Brown, K., 2014. A conceptualization of knowledge governance in project-based organizations. International Journal of Project Management, 32(8), 1411-1422.

88. Phang, C. W., Kankanhalli, A., and Sabherwal, R., 2009. Usability and sociability in online communities: a comparative study of knowledge seeking and contribution. Journal of the Association for Information Systems, 10(10), 721-747.

89. Polanyi, M., 1957. The tacit dimension. Garden City, NY: Anchor Books.

90. Poortvliet, P. M., Janssen, O., Van Yperen, N. W., and Van de Vliert, E., 2007. Achievement goals and interpersonal behavior: how mastery and performance goals shape information exchange. Personality and Social Psychology Bulletin, 33, 1435-1447.

91. Powers, V., 2004. Virtual communities at Caterpillar foster knowledge sharing. Training and Development, 58(6), 40-45.

92. Preece, J., 2004. Etiquette, empathy and trust in communities of practice: stepping stones to social capital, Journal of Universal Computing Science, 10(3), 294-302.

93. Quigley, N.R., Tesluk, P.E., Locke, E.A. and Bartol, K.M., 2007. A multilevel investigation of the motivational mechanisms underlying knowledge sharing and performance.

Organization Science, 18(1), 71-88

94. Reich, B.H., Gemino, A. and Sauer, C., 2012. Knowledge management and project-based knowledge in it projects: A model and preliminary empirical results. International Journal of Project Management. 30(6), 663-674. 
95. Roberts, P., 2006. Limits to communities of practice. Journal of Management Studies, 43(3), 623-639.

96. Ryan, R. M., and Deci, E. L., 2000. Self-determination theory and the facilitation of intrinsic motivation, social development, and well-being. American Psychologist, 55(1), 68.

97. Ryan, R.M., Stiller, J. and Lynch, J.H., 1994. Representations of relationships to teachers, parents and friends as predictors of academic motivation and self-esteem. Journal of Early Adolescence, 14, 226-249.

98. Scarbrough H., Bresnen M., Edelman L. F., Laurent, S., Newell, S. and Swan, J., 2004. The processes of project-based learning. Management Learning 35(4): 491-506.

99. Sense, A.J., 2011. The project workplace for organizational learning development. International Journal of Project Management. 29(8), 986-993.

100. Swan J., Scarbrough H. and Newell S., 2010. Why don't (or do) organizations learn from projects? Management Learning 41(3): 325-344.

101.Swan, J., Scarbrough, H. and Robertson, M., 2002. The construction of 'communities of practice' in the management of innovation. Management Learning, 33(4), 477-496.

102.Swanson, E. B., and Ramiller, N. C. 2004. Innovating Mindfully with Information Technology, MIS Quarterly, 28(4), 553-583.

103.Silva, L., Goel, L., and Mousavidin, E., 2009. Exploring the dynamics of blog communities: the case of MetaFilter. Information Systems Journal, 19(1), 55-81.

104.Songini, M.L., 2003. SAP pushes to increase use of its middleware. Computerworld, 37(36), 10.

105.Susman, G. I., and Everard, R. D., 1978. An assessment of the scientific merits of action research. Administrative Science Quarterly, 23(4), 582-603.

106. Szulanski, G., 1996. Exploring internal stickiness: impediments to the transfer of best practice within the firm. Strategic Knowledge Journal, 17, 27-43.

107. Tagliaventi, M. R. and Mattarelli, E., 2006. The role of networks of practice, value sharing and operational proximity in knowledge flows between professional groups. Human Relations, 59(3), 291.

108. Thompson, M., 2005. Structural and epistemic parameters in communities of practice. Organization Science, 16(2), 151-164.

109.Tsaturyan, T. and Müller, R., 2015. Integration and governance of multiple project management offices (PMOs) at large organizations. International Journal of Project Management, 33(5), 1098-1110.

110.Turner, N., Maylor, H., Lee-Kelley, L., Brady, T., Kutsch, E. and Carver, S., 2014. Ambidexterity and Knowledge Strategy in Major Projects: A Framework and Illustrative Case Study. Project Management Journal, 45(5), 44-55.

111.Turner, N., Maylor, H. and Swart, J., 2015. Ambidexterity in Projects: an Intellectual Capital Perspective. International Journal of Project Management, 33(1), 177-188.

112.Unger, B.N., Gemünden, H.G. and Aubry, M., 2012. The three roles of a project portfolio management office: their impact on portfolio management execution and success. International Journal of Project Management. 30, 608-620.

113. Van de Ven, A. H., 2005. Running in packs to develop knowledge intensive technologies. MIS Quarterly, 29(2), 368-378.

114.Vaast, E. and Walsham, G., 2009. Trans-situated learning: supporting a network of practice with an information infrastructure. Information Systems Research, 20(4), 547-564.

115.Vellerand, R. J., 1995. Toward a hierarchical model of intrinsic and extrinsic motivation, Canadian Psychology Association Annual Conference, June, Charlottetown, Prince Edward Island, Canada.

116. Von Hippel, E., 1994. 'Sticky information' and the locus of problem solving: implications for innovation. Management Science, 40(4), 429-439.

117.Von Hippel, E., 1998. Economics of product development by users: impact of 'sticky' local information. Management Science, 44(5), 629-644.

118. Wang P., Ramiller N. C., 2009. Community Learning in Information Technology Innovation. MIS Quarterly, 33(4), 709-734. 
119. Weick, K. E. and Roberts, K. H., 1994. Collective mind in organizations: heedful interrelating on flight decks. Administrative Science Quarterly, 3, 357-381.

120. Wenger, E., 1998. Communities of practice: learning, meaning and identity. Cambridge University Press, Cambridge.

121.Wenger, E. C., and Snyder, W. M., 2000. Communities of practice: the organizational frontier. Harvard Business Review, 78(1), 139-145.

122.Wenger, E.C., McDermott, R. and Snyder, W., 2002. Cultivating communities of practice: a guide to managing knowledge. Boston, M.A. Harvard Business School Publishing

123. Williams, T., 2008. How do organizations learn lessons from projects-and do they? IEEE Transactions on Engineering Management 55 (2), 248-266

124. Wittenbaum, G. M., Hollingshead, A. B. and Botero, I. C., 2004. From cooperative to motivated information sharing in groups: moving people beyond hidden profile paradigm. Communication Monograph, 71, 286-310. 


\begin{tabular}{|c|c|}
\hline The Mission Statement (MS) & Literature Basis \\
\hline $\begin{array}{l}\text { Our purpose is to provide a community where globally } \\
\text { dispersed Programme Office Managers can } \\
\text { collaborate to share expertise and ideas, learn from } \\
\text { each other, and move our Programme and Project } \\
\text { Management capability to "World Class" }\end{array}$ & $\begin{array}{l}\text { Brown and Duguid (2001); Lesser } \\
\text { and Everest (2001) } \\
\text { - Organization as CoP enabler, } \\
\text { providing clear directions and } \\
\text { structural support }\end{array}$ \\
\hline $\begin{array}{l}\text { By working together and sharing their expertise and } \\
\text { experience through a network of PMO managers, } \\
\text { members of the community will be able to develop } \\
\text { their knowledge of the PMO environment, so that their } \\
\text { work becomes more satisfying and rewarding, and less } \\
\text { frustrating. }\end{array}$ & $\begin{array}{l}\text { Gray (2004); Ma and Agarwal } \\
(2007) \\
\text { - A forum for collaborative } \\
\text { sharing and subsequent } \\
\text { dissemination }\end{array}$ \\
\hline $\begin{array}{l}\text { To achieve all of these intentions requires a } \\
\text { collaborative environment in which all community } \\
\text { members actively contribute and engage with fellow } \\
\text { members on a regular basis. }\end{array}$ & $\begin{array}{l}\text { Wenger (1998); Wenger and Snyder } \\
\text { (2000); Wenger, McDermott and } \\
\text { Snyder (2002) } \\
\text { - Participants with common } \\
\text { interest in a subject or goal } \\
\text { - Informal and spontaneous } \\
\text { - Peer-to-peer problem-solving } \\
\text { - Sharing best practices } \\
\text { - Generating new ideas and } \\
\text { innovations }\end{array}$ \\
\hline
\end{tabular}




\begin{tabular}{|c|c|}
\hline Terms of Reference (ToR) & Literature Basis \\
\hline $\begin{array}{l}\text { The Community-of-Practice is informal, self- } \\
\text { managed and self-organizing. Membership is } \\
\text { voluntary and open to all managers and staff working } \\
\text { in PMOs. } \\
\text { It should have a mission statement or terms of } \\
\text { reference that reflect both the organizational } \\
\text { contribution it intends to make and the benefits that } \\
\text { members of the community expect to gain. }\end{array}$ & $\begin{array}{l}\text { Wenger (1998); Wenger and Snyder } \\
\text { (2000); Wenger, McDermott and } \\
\text { Snyder (2002) } \\
\text { - } \quad \text { Participants with common interest } \\
\text { in a subject or goal } \\
\text { - } \quad \text { Informal and spontaneous } \\
\text { - } \quad \text { Peer-to-peer problem-solving } \\
\text { - Sharing best practices } \\
\text { - Generating new ideas and } \\
\text { innovations }\end{array}$ \\
\hline $\begin{array}{l}\text { The community should appoint a 'convener' } \\
\text { responsible for organizing and managing meetings } \\
\text { and following-up on actions agreed. } \\
\text { The community should also appoint a small 'core } \\
\text { team', to support the convener and to provide a } \\
\text { consistent presence at meetings. The core team will } \\
\text { assist in developing the community agenda, } \\
\text { monitoring agreed activities and obtaining } \\
\text { management approval for any specific resources or } \\
\text { funds required - for example for developing new } \\
\text { software. } \\
\text { The convener and core team will negotiate and agree } \\
\text { objectives for the community for a sensible period } \\
\text { (e.g. } 1 \text { year). A review of performance against the } \\
\text { objectives is to be conducted at the end of that period } \\
\text { to assess how well it has met the expectations of } \\
\text { community members. Objectives they may be } \\
\text { revised as and when important matters arise. }\end{array}$ & $\begin{array}{l}\text { Silva, Goel and Mousavidin (2009) } \\
\text { - } \quad \text { Explicit ground rules } \\
\text { - } \text { Presence of moderators } \\
\text { - } \text { Availability of profile information } \\
\text { - } \text { Tacit warrants for discerning } \\
\text { - } \text { pertinent posts } \\
\text { Deployment of specific } \\
\text { techniques of discipline }\end{array}$ \\
\hline
\end{tabular}




\begin{tabular}{|c|c|}
\hline $\begin{array}{l}\text { Each activity or priority task initiated and sponsored } \\
\text { by the community is to be delegated to those with a } \\
\text { particular interest in the matter to establish } \\
\text { objectives, host the event and engage with other } \\
\text { community members to carry it out. Any funding } \\
\text { required for the activities must be justified via a } \\
\text { business case. }\end{array}$ & \\
\hline $\begin{array}{l}\text { Community activities including attendance at } \\
\text { meetings should be seen as a legitimate part of the } \\
\text { individual's job, not an extra activity, as should any } \\
\text { actions undertaken by individuals on behalf of the } \\
\text { community. This should be explicitly supported by } \\
\text { the PMO managers' line management. } \\
\text { Members should be encouraged to express and test } \\
\text { their opinions and ideas in an open and risk free } \\
\text { environment. 'There is no such thing as a silly } \\
\text { question!' } \\
\text { It is important to explicitly recognise the } \\
\text { contributions individuals make to the community } \\
\text { activities, both to their management and to other } \\
\text { community members. }\end{array}$ & $\begin{array}{l}\text { Charalambos, Machalinos and } \\
\text { Chamberlain (2004) } \\
\text { - Giving ownership to participants } \\
\text { - Ensuring commitment } \\
\text { - Incentivizing and compensating } \\
\text { - for good and bad exchanges } \\
\text { - Implementing appropriate } \\
\text { institutional policies }\end{array}$ \\
\hline $\begin{array}{l}\text { The community should be supported by the } \\
\text { appropriate technology and facilities for exchanging } \\
\text { information, collaborative working and establishing } \\
\text { a Knowledge Centre as resource for members to } \\
\text { contribute to and access. A process for maintaining } \\
\text { the content (currency and integrity) of the } \\
\text { Knowledge Centre should be determined. }\end{array}$ & $\begin{array}{l}\text { De Souza and Preece (2004); Preece } \\
\text { (2004); Phang, Kankanhalli, and } \\
\text { Sabherwal (2008) } \\
\text { - Open online interactions } \\
\text { - Community policies and rules } \\
\text { - Accessible, reliable and easy to } \\
\quad \text { use with appropriate tools }\end{array}$ \\
\hline
\end{tabular}

